\title{
LA AUTO-REPRESENTACIÓN DE LA IDENTIDAD DEL SUJETO A TRAVÉS DE SU AVATAR EN LOS MMORPGS
}

\section{Por: Rodrigo Molina Valencia}

Estudiante de Diseño Gráfico

nickolay_vladuss@hotmail.com

\section{Tatiana Cuéllar Torres}

Maestra en Artes Visuales en Comunicación y Diseño Gráfico

Profesora del Departamento de Diseño

Universidad del Valle

tatiana.cuellar@correounivalle.edu.co

Resumen: La presente revisión teórica identifica algunos de los elementos de la representación de la identidad de un sujeto a través de la construcción de su Avatar en los MMORPGs o juegos multi-jugador masivos de rol en línea. Este estudio supone una perspectiva ontológica, evidencia una multiplicidad de enfoques y hace consideraciones acerca de las dimensiones sociales, lúdicas y narrativas que, poniendo especial atención en los aspectos individuales del jugador, permiten analizar, posteriormente, las relaciones entre la identidad en el jugador y la representación en el avatar. Como resultado de este abordaje, se espera obtener un panorama general sobre las concepciones actuales de identidad e imagen, la relación sujeto-avatar, a través de un análisis semiótico.

Palabras Clave: MMORPGs, identidad, rol, avatar, representación, imagen, sujeto, subjetividad, semiótica, sentido.

Abstract: This theorist review identifies some of the elements of the representation of the identity of a subject through the construction of its Avatar en the MMORPGS or massive multiplayers games of rol on-line. This study supposes an ontological point of view, shows a multiplicity of perspectives and makes considerations about the social, ludical and narratives dimmensions that, taking a special emphasis in the individual aspects of the gamer, allow to analyze the relationships between the identity in the gamer and the representation in the avatar. As the result of this work, it is hoped to obtain a general view on the actual conceptions of identity and image, the relation subjecto-avatar, through a semiotic analysis.

Keywords: MMORPGs, identity, rol, avatar, representation, image, subject, subjectivity, semiotics, sense. 


\section{Introducción}

Los MMORPGs (Massive Multiplayer On line Role Playing Game) o juegos multi-jugador masivos de rol en línea, son juegos de video que reúnen a usuarios de todo el mundo en tiempo real y en un mismo escenario, permitiéndoles interactuar entre ellos y a través del mundo virtual, utilizando como representación de sí mismos una figura denominada Avatar.

En esta dirección, se entiende que algunos aspectos de la identidad como tal en los MMORPGs, se expresan en las representaciones de imágenes que el sujeto configura (Avatar), las cuales varían de juego en juego dependiendo de su diseño. Sin embargo, estas variaciones parecen compartir un núcleo común relacionado con la auto-imagen del jugador, sus características emocionales y expectativas, abordadas teóricamente en este artículo.

Los avatares como unidad de análisis permiten observar cómo las personas representan su imagen deseada tal vez ideal-, a través de elementos gráficos, y cómo media la subjetivación en estos procesos. Este enfoque analiza la auto-representación de la identidad del jugador adoptando el punto de vista del avatar, en primer lugar, para -luego- volver a centrarse en el sujeto. Examinar el avatar y luego al sujeto es la opción de estudio y aproximación que hemos escogido, y confiamos en que podremos justificar, explicar y demostrar la validez de este enfoque desde una perspectiva ontológica.

\section{Construcción del objeto de estudio}

Para este estudio se revisaron 45 artículos que se ocupan de las relaciones entre juegos de video e internet y las identidades e imágenes personales. También se examinaron 7 libros que abordan algunos aspectos sociológicos y psicológicos referidos tanto a patrones de comportamiento y tendencia de los jugadores, como a concepciones sobre identidad, subjetividad y sujeto. Se trata, en todos los casos, de estudios exploratorios relacionados con los juegos en línea.

Uno de los artículos que cimenta este estudio es $L a$ construcción de sociedades virtuales entre los jugadores masivos en internet, escrito por Hernández y Hernández en 2009. En este artículo aborda de manera exploratoria los MMORPGS, tomando como caso de estudio World of Warcraft ${ }^{1}$. Para los autores, el objetivo del artículo es "analizar, desde una perspectiva sociológica, la construcción de sujetos virtuales en las interacciones simbólicas, que al interior del juego conforman sociedades y códigos sociales equivalentes a los de las realidades concretas" (221). Este trabajo aporta referencias y elementos conceptuales que nos permiten delimitar nuestro objeto de estudio.

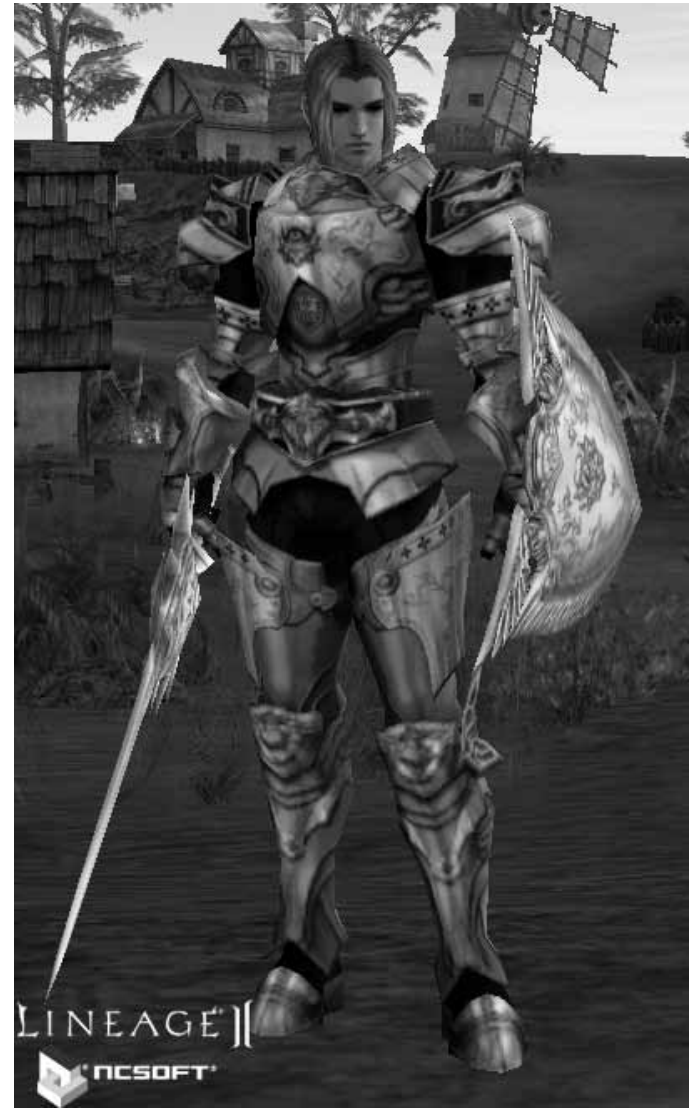

Figura 1. Avatar del juego Lineage 2. 
En Videojuegos MMORPG, conceptos, características, problemáticas y posibilidades escrito por Piuzzi (2010), se hace una revisión de los puntos característicos de los MMORPGs desde su historia, géneros e implicaciones de su uso. Aunque más reciente que el trabajo de Hernández y Hernández (2009), el estudio de Piuzzi se queda en generalidades y hace una descripción superficial del fenómeno. Por el contrario, en el caso del trabajo de Hernández y Hernández (2009), aunque lo que se aborda sobre la imagen aparentemente es poco por su naturaleza descriptiva y por su enfoque, desarrolla, apelando a Jean Baudrillard y Michel Foucault, interesantes elementos y líneas de reflexión sobre imágenes ideales, representación, prototipos y alegoría.

El artículo de Hernández y Hernández (2009), nos llevó a preguntarnos ¿cómo se configura la identidad de un sujeto en función de una imagen o serie de imágenes ideales en la creación de personajes en los MMORPG? Por supuesto, la pregunta se ha ido transformando en el transcurso de la investigación, pero sigue privilegiando algunos conceptos y problemas básicos: construcción, configuración, sujeto, identidad, subjetividad e imagen. Cada uno de ellos irá ganando en precisión y claridad terminológicas, para avanzar en una mejor delimitación del objeto de estudio.

Sibila (2008) en su libro La intimidad como espectáculo, explora las distintas facetas del sujeto en sus múltiples representaciones, dentro de entornos web. En cada capítulo aborda un componente del Yo frente a distintas interacciones con la sociedad, esencialmente las tecnológicas. En el capítulo 8, llamado Yo personaje y el pánico a la soledad, se plantea la siguiente pregunta:

¿Cuál es la principal obra que producen los autoresnarradores de los nuevos géneros confesionales de internet? Esa obra es un personaje llamado Yo. Lo que se crea y recrea incesantemente en esos espacios interactivos es la propia personalidad, esta personalidad se hace visible como una subjetividad ya sea de tipo alterdirigido (orientada a los demás) o introdirigido (orientado a sí mismo) (Sibila, 2008: 265).

En esta misma dirección, Esnaola (2006) se aproxima a la relación sujeto-MMORPG desde la antropología simbólica, y propone que el sujeto se define como un Yo separado del mundo externo pero formado en diálogo continuo con los mundos culturales externos, de forma que:

El sujeto mediatiza los valores, sentimientos y símbolos de la cultura, incorporándolos como imaginario colectivo y transforma sus deseos en necesidades, tal como impone la cultura del consumo. Estas características del momento histórico cultural y las experiencias vividas por el sujeto inciden en la construcción de la identidad ya que la dinámica psíquica simbólica investirá de sentido lo vivido (Esnaola, 2006:128). 
La autora explica que el lugar que ocupan los sujetos como espectadores, les posibilita identificarse con lo que sucede a los personajes en las historias y desarrollar fantasías de amor y odio sobre los héroes y villanos. Esto permite que se diluya la fantasía oculta bajo la identificación con el narrador, y el sujeto puede implicarse en el mundo de la ficción que él mismo ha construido (Esnaola, 2006: 91).

Mediante estos argumentos se busca entender la representación del mundo exterior a través de objetos simbólicos insertos en un espacio de transición. Este espacio entre la realidad interna y la externa del sujeto, utiliza determinados vehículos emocionales especialmente propicios para generarlos. Estos objetos materiales y simbólicos son contenedores que el medio cultural le acerca a los sujetos y que ellos invisten de contenidos emocionales propios.

Desde esta perspectiva, la narración constituye una construcción de objetos transicionales:

Suponemos que los videojuegos -en tanto, objetos lúdicos extendidos en el tiempo de inmersión participativa de los usuarios- intervienen en el proceso de construcción de la identidad social facilitando arquetipos de identificación que operan como imágenes proyectivas de contenidos simbólicos culturalmente construidos. Mediante este mecanismo, las tendencias pulsionales reprimidas se proyectan al exterior sobre imágenes u objetos de la cultura con la ventaja que el sujeto puede así expresarse sin angustia (Esnaola, 2006:128).

Para efectos prácticos de la construcción del argumento, Esnaola (2006) sostiene que la identificación no consiste en una simple imitación, se realiza en las representaciones de imágenes que el sujeto construye de la persona con la cual se identifica.Y el paso de las identificaciones a la identidad se evidencia por el tránsito que realiza el sujeto desde los primeros vínculos afectivos con los objetos amorosos tempranos hacia una construcción progresiva más estable que supone una integración desarrollada por él mismo.

Como aporte final, la autora concluye que el logro de la identidad supondría entonces un núcleo personal y autónomo caracterizado por los sentimientos básicos de unidad, mimisidad y continuidad; permitiendo que el personaje, que deviene en arquetipos de identificación, le posibilite al usuario la proyección imaginaria de sus contenidos afectivos. Así pues, la imagen remite a significaciones profundas con lo cual el límite entre lo real y lo virtual se pierde (Esnaola, 2006:128). Límite al cual Hernández y Hernández (2009) aluden citando a Baudrillard, cuando se refieren a la imagen que suplanta a la realidad. Esta suplantación lleva a ver y pensar el estatuto del sujeto desde otro nivel, el de la ficción, de ficción, porque resignifica en un espacio virtual las formas de interacción social de su mundo "real" para forjar otras identidades. Básicamente, este enunciado plantea dos problemas conceptuales que es necesario revisar: el primero relacionado con la imagen y el segundo con la identidad (Hernández \& Hernández, 2009:222). 
Hernández y Hernández (2009) se preguntan “ipor qué en aras de la diversión un individuo se construye como sujeto virtual de una realidad ficticia y cómo se realiza este proceso?” " ¿hay en este tipo de experiencia alguna correspondencia entre lo real concreto y lo real individual?". Para Esnaola (2006) en el caso de los juegos en línea, lo anterior ocurre cuando el sujeto anónimo crea un personaje en el mundo de la ficción del MMORPG, comprometiéndose con las reglas, códigos de conducta y de acción anteriormente planteados. Sobre ello, considera que el pacto inicial de inmersión narrativa se establece, cuando el usuario elige un nombre para el personaje que desarrolla la trama narrativa (Esnaola, 2006:141).

El grueso de los autores consultados hablan de la mecánica del fenómeno, haciendo evidente parte del proceso, pero desde un enfoque psicosocial, que aborda el tema de la identidad tangencialmente.

Salazar (2005) en su documento On the Ontology ${ }^{2}$ of MMORPG Beings: A theoretical model for research, aborda el problema de la creación de personajes en los MMORPG, formulando una metodología más completa. Salazar (2005) sostiene que en el campo de estos estudios sobre los juegos de rol en línea y el estudio específico de los MMORPGs, se han enfocado en cuatro aspectos: los tradicionalmente sociales, los referidos a la individualidad del jugador, los narratológicos y los ludológicos. Para el autor, aunque estos no se excluyen mutuamente, enfocarse en uno o dos genera vacíos conceptuales y experimentales importantes.

Pérez (2006) tiene una postura similar y subraya la importancia de reconocer en los estudios sobre MMORPGs la presencia de aportes que vienen de la ludología, la narratología, la simulación, la semiótica, la pedagogía, los estudios culturales y los estudios sobre efectos psicosociales. La diferencia entre estos dos documentos radica principalmente en el objeto empírico estudiado: mientras el interés de Salazar (2005) radica en los avatares como 'seres' de los MMORPGs, Pérez (2006) se centra más en el videojuego como objeto comunicativo.

124 Por otro lado, en el artículo de Salazar (2005) se evidencian ciertos problemas: asume que los MMORPGs en sí son espacios sociales y cae en imprecisiones ya que, según Salazar, no es sólo el espacio el que se presta para la sociabilidad de los jugadores, si no que los jugadores que lo habitan son portadores de esa sociabilidad, lo cual deriva en una confusión al dar por sentado la naturaleza individual del jugador en tanto ser social. Salazar (2005) también sostiene que, si se asume que los personajes o avatares son las entidades básicas que portan la sociabilidad en los MMORPGs, también se necesita explicar el proceso de subjetivación, que ocurre a nivel individual, como resultado de la adición de sociabilidad a estas entidades, un aspecto que, según Salazar (2005), tiende a olvidarse (Salazar, 2005:2). Sin embargo, el autor hace evidentes otras características que suelen soslayarse en este tipo de estudios como la configuración de todos estos elementos para construir la entidad como tal, el papel fundamental que juegan los contenidos preexistentes en el jugador (deseos, personalidad, expectativas, etc.), y la falta de análisis de los aspectos narratológicos, es decir, de la capacidad de reproducción semiótica de los avatares. Salazar (2005) advierte lo siguiente: 
El “avatar” es una mezcla de líneas de código y la subjetividad del jugador. En los MMORPGs los jugadores tienen una gran variedad de opciones de personalización para su avatar, donde usualmente los jugadores configuran sus personajes con características que reflejan sus decisiones, expectativas, necesidades etc. Al punto que el avatar gráfico es el reflejo de la subjetividad del jugador (Salazar, 2005:11).

Salazar (2005) grafica su planteamiento de la siguiente manera:

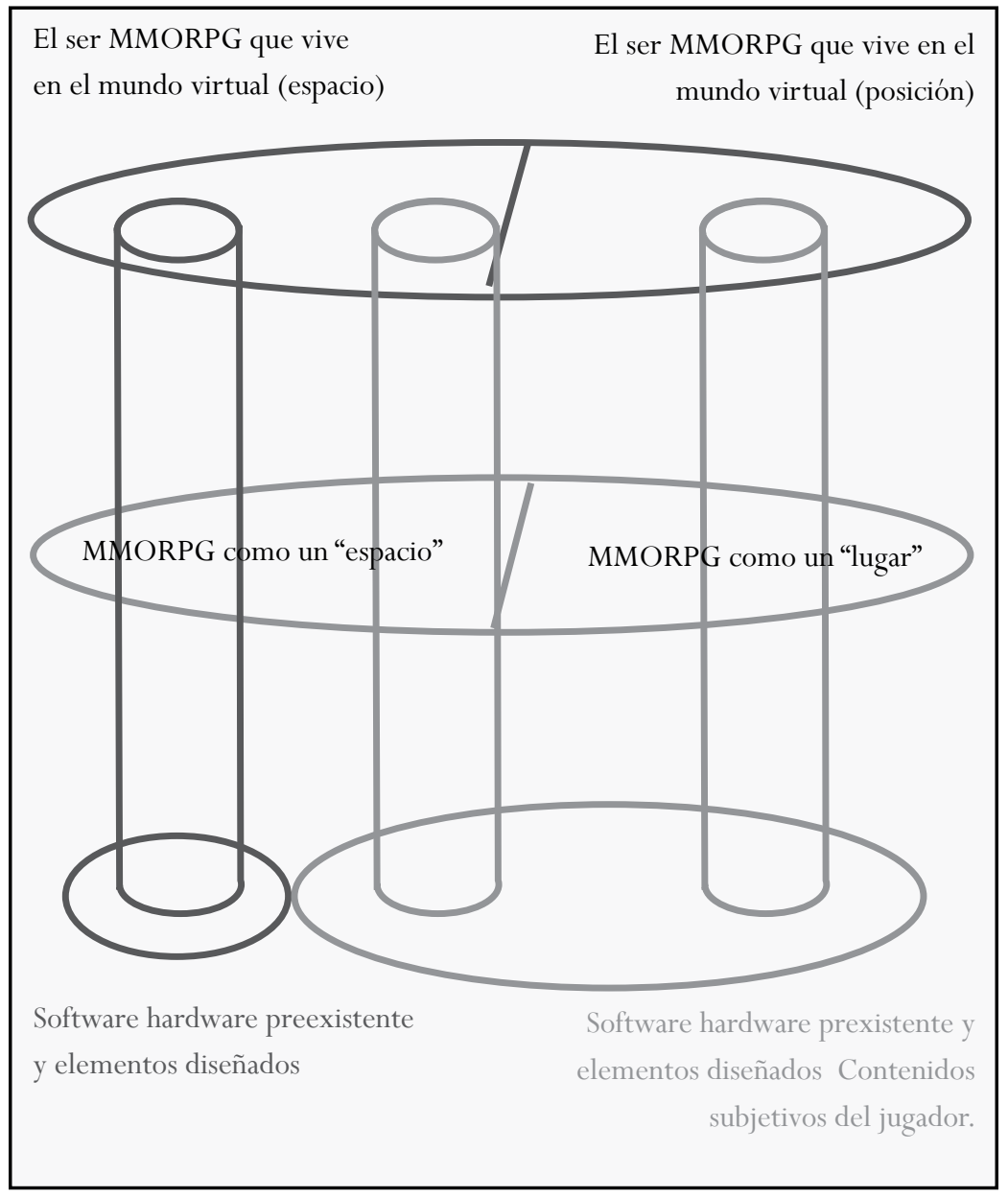

Figura 2. Planteamiento de la estructura del avatar por Salazar (2005).

En esta dirección, los trabajos de Salazar, Pérez y Hernández, D. y Hernández, M., posibilitan entender trabajos posteriores y algunos mucho más especializados, al ofrecer algunos elementos conceptuales y metodológicos precisos. En este punto, pasar de la cuestión de los MMORPGs, al avatar como representación gráfica de la subjetividad del jugador y como imagen portadora de sentido y posición en el mundo virtual de los MMORPGs, permite acercarse más a la pregunta que compete a este trabajo. 
Para ello es esencial, por un lado, avanzar algunos apuntes acerca de las relaciones entre el ser humano y los nuevos medios tecnológicos, y por el otro, referir algunas visiones que investigadores tienen acerca del estatuto del avatar y sus relaciones con el sujeto, la imagen y con el público en general. En esta dirección, los estudios de Turkle (1997) proveen un registro de hechos sociales determinantes en la relación del ser humano con los computadores y las interfaces de las mismas, desde la introducción de la ventana en los computadores, hasta los MUDs como antecesores de los juegos en línea actuales. En la vida en pantalla (1997) Turkle hace una profunda reflexión sobre el papel que juega la tecnología en la creación de nuevos mundos y sensibilidades, y subraya el estatuto antropológico de la tecnología: "hemos utilizado nuestras relaciones con la tecnología como un reflejo de lo humano" (Turkle, 1997:34).

Por otro lado, autores como Matviyenko (2010), Kromand (2007) y Hamilton (2009) hacen aportes claves para entender la concepción del avatar y las relaciones de identificación con los usuarios. Hamilton (2009) retoma algunas ideas de Turkle, actualizándolas a los entornos gráficos ampliamente desarrollados de la última década, trabajando sobre las funciones del avatar y destacando aquellas áreas de conocimiento desde las cuales este fenómeno puede ser estudiado. Kromand piensa los avatares en función de su diseño, aportando a su vez, definiciones de algunas de sus características. Finalmente Matviyenko plantea la relación del avatar con el sujeto en tanto prótesis. Pensado como prótesis del sujeto, la noción de avatar cobra una relevancia renovada.

Para finalizar, en Persistent Rhetoric for Persistent Worlds: The Mutability of the Self in Massively Multiplayer Online Role-Playing Games escrito por Bates (2009), el autor trata de mostrar cómo los procesos de identidad son creados mediante acciones retóricas. Para ello trabaja a través de dos MMORPGs: Ultima Online y World of Warcraft. Explora ambos juegos usando como referencias a autores como Barney Glaser y Anselm Strauss. Bates (2009) analiza las particularidades del proceso de creación de la identidad en distintos contextos del mundo virtual, con un enfoque profundamente comunicativo. Encuentra dos tipos de personajes a través de una caracterización retórica y la construcción de los esquemas de identidad que se ponen en marcha durante, el juego y más allá de ello.

En conclusión, a través de los autores revisados encontramos elementos para pensar la auto-representación de la identidad del jugador a través de la imagen como objeto de estudio, lo que nos permitirá abordar los avatares como unidad de análisis. Los trabajos de Salazar (2005) y Pérez (2006) plantean una metodología y un rigor para tratar el fenómeno, Turkle (1997) por su parte aporta antecedentes y pistas claves para entender el fenómeno, y finalmente Matviyenko (2010), Kromand (2007) y Hamilton (2009) muestran enfoques útiles, tal como indicaremos a continuación. Si además tenemos en cuenta el trabajo alrededor de la imagen de autores como Belting Cassier y Moles, podemos encontrar los puntos de convergencia sobre el tema del avatar y la particular relación simbólica entre significante e imagen como mecanismo fundamental de la representación. 


\section{Desarrollo teórico del objeto de estudio}

El avatar en los MMORPGs, desde el punto de vista ontológico de Salazar (2005), se compone de cuatro aspectos abordados por cuatro tradiciones de investigación: el narratológico, el lúdico, el social y los idiosincráticos o referidos al sujeto. En el último aspecto es posible identificar las particularidades sujeto-avatar de interés para este estudio, especialmente en el momento en que el jugador crea el personaje en el MMORPG.

Así, establecer la relación entre estas cuatro tradiciones investigativas en el funcionamiento de las formas de representación e identidad en los juegos masivos de rol en línea, sin obviar ninguna de ellas, será de gran importancia para establecer un marco teórico de referencia que permita alejarse de la confusión y la ambivalencia que podrían resultar al ignorar cualquiera de los cuatro aspectos identificados.

\section{Aspecto narratológico}

En relación con la dimensión narratológica, Jerome Bruner en La fábrica de historias (2003), explica que los relatos son procesos tan naturales en la vida cotidiana, que se da por descontado cómo funcionan: eso lleva a una profunda dificultad para tratar de explicar el cómo del relato. Es fácil usar relatos, pero difícil comprender cómo se constituyen. Para Bruner (2003) la cuestión puede explicarse debido a que el relato considera una estructura sutil y cierta intención oculta contenida en el hecho mismo de narrar, y ambos aspectos no son transparentes ni fácilmente reconocibles. Otro aspecto interesante es el hecho de que el relato se suele entender y asumir como si fuera la realidad misma (lo que es) y no como algo que le da forma a lo real.

Pérez (2006) se aproxima a la dimensión narrativa a partir de la Gramática del Relato de Tzvetan Todorov, que define el relato como el tránsito desde un estado en el que se rompe el equilibrio inicial hasta otro estado en el que finalmente se ha recuperado el equilibrio (Pérez, 2006:58). También Bruner retoma esta idea a partir de la noción aristotélica de peripeteia, que se basa en la noción de ruptura como motor de la construcción narrativa (Bruner, 2003:4).

Estos modelos de realidad narrativa, fundados en la idea de ruptura y equilibrio, son los que este estudio explora y mediante los cuales posiblemente se constituye la realidad narrativa del sujeto jugador. Citando a Bruner (2003): "Esta capacidad que tiene el relato de modelar la experiencia no puede ser atribuida simplemente a un enésimo error en el esfuerzo humano por dar sentido al mundo" (24). Estos esfuerzos fuera de darle sentido al mundo, terminan por modelar la forma de narrar o referenciar la vida misma. En el caso de los MMORPGs, estos sentidos modelan profundamente la experiencia de juego del sujeto y hacen parte de la construcción del sentido de sí mismo del jugador. 
En esta dirección, Salazar (2005) considera las narrativas como parte del contenido cultural que se reproduce dentro del MMORPG. Estas narrativas son resultado de actividades semióticas, creadas por sujetos. Plantea que necesariamente las "narrativas" dependen de una capacidad esencial de reproducción simbólica/semiótica, que no puede darse por descontado, una que se encuentra en el día a día de cada persona, sin la cual el pensamiento y la comunicación probablemente no existirían (Salazar, 2005).

En la mayoría de los casos, la forma en la que se explican las situaciones del cotidiano, están mediadas por múltiples referencias literarias, y en estos tiempos del video, el cine y la televisión, por múltiples referencias audiovisuales. Los elementos de la narrativa por muy fantásticos que parezcan, se transforman en ventanas que ayudan a vislumbrar la realidad, no necesariamente por que enseñen y manifiesten de manera transparente, sino por el tipo de procesos que implica la puesta en relato. En palabras de Bruner (2003): "Así mismo sabemos que la ficción literaria, aunque se comporte como lo familiar, tiene el objetivo de superarlo para adentrarse en el reino de lo posible, de lo que podrá ser/ haber sido/acaso ser en el futuro" (29). Mediante estos desdoblamientos, se manifiestan múltiples representaciones del sujeto como parte de la expresión de identidad. El Yo es probablemente la más notable obra de arte que producimos en momento alguno, con seguridad la más compleja, puesto que no creamos un solo tipo de relato productor del Yo, sino gran cantidad de Yos, tal como lo dicen los versos de Eliot:

Preparamos un rostro para encontrar

Los rostros que encontramos.

Bruner nos recuerda que se trata de agrupar estos Yo "en una sola identidad, poniéndolos en hilera por orden cronológico (...) Pues lo que intentamos corroborar no es simplemente quienes y qué somos, sino quienes y qué podríamos haber sido, dados los lazos que la memoria y la cultura nos imponen, lazos de los que muchas veces no somos conscientes" (Bruner, 2003:30).

Graciela Alicia Esnaola (2006) habla de la posibilidad de representar el mundo interno, que se desarrolla a través de diferentes herramientas culturales. Para ella sin embargo, en las diversas modalidades (narraciones literarias y narraciones escenificadas) se conserva la posibilidad de establecer una suerte de frontera entre el espacio del sujeto y de la obra: la construcción de un espacio de transición que permite jugar con las fantasías propias, con la seguridad que se cuenta con la "cuarta pared", que mantiene al sujeto fuera de escena. Algo de lo que Bruner se ocupa (2003) cuando argumenta cómo "las metáforas de la literatura que nos protegen del impacto seco del terror de lo posible" (78). 


\section{Citando a Esnaola (2006):}

Nuestro lugar de espectadores nos posibilita poder identificarnos con lo que sucede a los personajes y desarrollar las fantasías de amor y odio sobre los héroes y villanos. En la narrativa participativa, los sucesos que son relatados por un narrador externo a nuestra propia voz quedan paulatinamente destruidos. Hemos comenzado a desilusionarnos entrando en la escena, perforando la "cuarta pared". En una narrativa de inmersión dramática las emociones y las fantasías más arcaicas aparecen iluminadas con una crudeza tal que nos descontrola. La fantasía oculta bajo la identificación con el narrador queda diluida y podemos implicarnos en el mundo de la ficción que nosotros mismos hemos construido (Esnaola, 2006:91).

Ciertamente estos mecanismos narrativos de identificación son fundamentales en el acto mismo de la representación, permitiendo entender cómo median los contenidos individuales y culturales de un sujeto en la posibilidad misma de representar.

Por otro lado, Bruner (2003) entiende que la construcción narrativa que transforma las situaciones privadas en aspectos públicos, si está bien desarrollada confiere gran poder de transformación cultural. Así, no sólo se le está dando vida a un personaje cuando se lo crea, también nos da la posibilidad de entenderlo y que el auditorio se vea reflejado en él, en sus problemas y posibilidades. "La literatura imita con astucia la realidad convencional para crear verosimilitud” (Bruner, 2003:72). Esta posibilidad literaria presenta oportunidades interpretativas en el discurso que compone al personaje, de forma que:

La narrativa es el médium por excelencia para describir, o inclusive caricaturizar, situaciones humanas, como en las historias de "niños perdidos" o "enamorados celosos" y -porque no- cuando la common law hace referencia a la moderna misericordia. Las situaciones prototípicas llegan a tornarse metáforas fundamentales de la condición humana; como Sísifo, que carga perpetuamente su roca cuesta arriba, metáfora fundamental de la frustración que se nutre a si misma (Bruner, 2003:87).

Es así como hay un poder mediador en la narrativa que facilita y media en los procesos de identidad, al igual que unos marcos de referencia o prototipos que pasan a ser elementos de representación, lo que permite reflexionar sobre las referencias empleadas para representar y el peso que la narrativa tiene en la construcción mental humana y la estructuración de la identidad. En el caso específico de los MMORPGs, vale la pena volver a citar a Bruner (2003): 
Comenzaré afirmando resueltamente que en efecto no es dado conocer un Yo intuitivamente evidente y esencial, que aguarde plácidamente ser representado con palabras. Más bien, nosotros construimos y reconstruimos continuamente un Yo, según lo quiera las situaciones que encontramos, con la guía de nuestros recuerdos del pasado y de nuestras experiencias y miedos para el futuro (Bruner, 2003:93).

En cuanto a los MMORPGs, el aspecto narrativo es mucho más evidente en los 'cambios de estado', generados por la ruptura que crea el suceso. El jugador en un principio posee un bagaje histórico y cultural propio debido a sus trayectorias relacionadas con su condición étnica, sexual, profesional, de clase, etc, pero este bagaje histórico será ajustado y adaptado en cierta medida por el jugador durante el juego como parte de la construcción de una historia personal (la historia del personaje), que se desarrolla a medida que el jugador experimenta el MMORPG. Para construir el personaje, el jugador se basa, además de su experiencia y condición histórica, cultural y social, en esquemas narrativos (tomados de la literatura, teatro, video, cine, televisión, etc.) que traduce, caracteriza y representa en situaciones prototípicas durante el juego.

Finalmente, la narrativa como medio de construcción mental y el lenguaje como medio de expresión, se integran a los otros tres aspectos considerados en este estudio.

\section{Aspectos lúdicos}

Sobre el desarrollo de la dimensión lúdica del problema, entendida como experiencia profundamente humana y placentera, Esnaola afirma que:

Los videojuegos -entendiéndose como objetos lúdicos extendidos en el tiempo de inmersión participativa de los usuarios- intervienen en el proceso de construcción de la identidad social, facilitando arquetipos de identificación que operan como imágenes proyectivas de contenidos simbólicos culturalmente construidos, cuyas imágenes remiten a significaciones profundas" (Esnaola, 2006:128).

La inmersión en el juego implica moderar la distinción entre lo real y lo virtual. "Mediante este mecanismo, las tendencias pulsionales reprimidas se proyectan al exterior sobre imágenes u objetos de la cultura con la ventaja que el sujeto puede así expresarse sin angustia” (Esnaola, 2006:128).

Este escenario de disolución- fragmentación y reagrupamientos identificatorios que analíticamente nos presenta Esnaola, ilustra una de las características de la identidad en la contemporaneidad, y cómo el sujeto las asume en los ambientes virtuales, junto a los profundos mecanismos de representación impulsados por estas proyecciones. Muchas de las formas de relación y representación del pasado se desplazan, pero no desaparecen, solo se condicionan a un nuevo canal y nuevos contextos. Y como la construcción de la identidad implica el diálogo y tensión entre las distintas imágenes que la persona tiene de sí misma en la cultura en que vive, los entornos virtuales parecen multiplicar la posibilidad de poner en juego esas múltiples representaciones de sí. Sobre ello Esnaola (2004) explica que: 
En el espacio lúdico de los videojuegos el Otro aparece, según sea los lugares sociales, tanto como un oponente, un rival peligroso o un enemigo al que hay que eludir o destruir. Pero también, el otro puede constituirse en un próximo con quien entablar un vínculo solidario (Esnaola, 2004:93).

Las relaciones entre las cuatro dimensiones o aspectos considerados en este estudio se cruzan a lo largo de la experiencia del sujeto jugador, y trascienden las variables de tipo lúdico como son el juego, la jugabilidad y reglas de juego, pues estas variables dependen de las experiencias previas del jugador, y de contenidos culturales que operan como mediadores de sentido (por ejemplo, las expectativas de las que nos habla Salazar (2005) o las formas de narración e identificación que facilita la narrativa, tal como nos explica Bruner (2003)).

Las mismas reglas de juego son modificadas según el sentido que le dé el jugador, de la misma forma, los esquemas preexistentes en el jugador pueden ser rotos o modificados dependiendo de la estructura del juego y la interacción con los otros jugadores. Diversas dimensiones sociales e individuales definen la forma en que el sujeto afronta el juego y modulan y varían la experiencia de inmersión, identificación o las sensaciones de presencia mientras juega. Sin embargo, es desde el juego y sus posibilidades que se desarrolla la capacidad de anticiparse a los sucesos, proponer soluciones y problemas hipotéticos. A partir de los aportes del Donald Woods Winnicott, el célebre psicoanalista, psiquiátra y pediatra inglés, Esnaola (2004) subraya la importancia de la actividad lúdica como promotora de procesos de simbolización, interacción y expresión de las emociones, lo que le lleva a considerar al juego como un medio necesario para el desarrollo cognitivo en tanto expresión privilegiada de la función simbólica infantil (Esnaola, 2004:152).

De acuerdo a lo anterior, Esnaola (2004) sostiene que jugar es, indudablemente, una fuente principal de aprendizaje, ya que a partir de estos modelos de comportamiento se construye lo que la persona puede llegar a ser como parte de la experimentación con su identidad. Dadas las características actuales de los objetos con los cuales los niños aprenden a jugar, Esnaola (2004) entiende que el espacio lúdico alude a algo más que al juego en sí mismo y considera el plano simbólico en la propia actividad:

Ya Freud, desde sus escritos analíticos había observado que un niño cuando jugaba con un carretel, decía "ford" cuando se alejaba y "da" cuando regresaba. Infirió a partir de este hecho que el niño simbolizaba la presencia / ausencia de su madre. A través de este juego el niño estaba inscribiendo y escribiendo en esa actividad, contenidos del orden del inconsciente. Al tomar elementos de su entorno, el sujeto inscribe y elabora simbólicamente, su propia historia. Lo logra a través del juego. Y nadie puede remplazarlo en esta trabajosa empresa. Para ello la actividad lúdica se instala como "protoescritura" que le permite relaborar en el plano de lo simbólico, un espacio transicional construido en un espacio intermedio entre el sujeto y la realidad externa (Esnaola, 2004:152). 
El juego permite al sujeto transformar objetos en objetos simbólicos portadores de otros sentidos: así una caja se vuelve una casa y una montaña de tierra un castillo. Mediante este proceso el sujeto explora su individualidad, su imagen en contraposición con la del otro y su subjetividad como recreación de sí mismo. Para Esnaola (2004) lo lúdico, instalado en el espacio transicional y simbólico, posibilita el aprendizaje de manera privilegiada:

El juego aporta reglas y una representación de lo posible a la actividad lúdica, permite simular decisiones en un mundo de representaciones. De no existir estas características estaríamos hablando de simple entretenimiento, un pasatiempo que no instala la posibilidad de diseñar aquella "protoescritura singular" (Esnaola, 2004:153).

Lo anterior no es solo observable en los MMORPGs, sino también en los juegos televisados populares como Quién quiere ser millonario, libros con Caminos para escoger o el reality show, que hacen parte del goce de la elección, no una basada en el peso y la responsabilidad de la consecuencia, si no, en el poder -así sea ilusorio- de la elección.

Es así como juego y narrativa son transformados en aspectos simbólicos y comunicacionales, que median la experiencia del sujeto con la realidad cotidiana, de la misma forma que posibilitan adjudicar sentido a las imágenes prediseñadas en los MMORPGs de forma no totalmente arbitraria, si no, a través de significados culturales y personales a nivel de la experiencia, significados que son representados y pueden ser rastreados. Para Esnaola (2004), el juego se proyecta más allá del simple placer individual:

No consideramos el juego como una función aislada, sino como una forma de actividad solidaria de un desarrollo más general. La teoría socio-cultural considera el origen social de los procesos mentales superiores y el papel del lenguaje y de la cultura en tanto mediadores necesarios para la construcción y la interpretación de los significados de las actividades que desarrollamos en la vida cotidiana. Vigotsky, ya desde sus escritos iniciales, postula la ley de doble formación de los conceptos que seguiría un proceso espiralado y vinculante desde lo intersubjetivo hacia lo intrasubjetivo. En este sentido sostenemos que el juego configura la primera experiencia de "autoría del sujeto" que le posibilita llevar a cabo la experiencia de tomar la realidad del objeto y transformarla aceptando sus límites. Precisamente es en ese espacio transicional, intersubjetivo, el lugar donde nace el pensamiento en su búsqueda por resolver el desafío que lo moviliza. Este movimiento "subjetivante" posibilita que la inteligencia se motorice hacia el despliegue de su energía creativa promoviendo la actividad propia de cada sujeto (Esnaola, 2004:153). 
Como se puede ver, estas experiencias están profundamente asociadas al desarrollo de la personalidad, de nuestros marcos conceptuales, estéticos y emocionales. Los MMORPGs poseen este potencial transformador al aportarle al sujeto un espacio apropiable, elementos referenciales y posibilidades sociales mediante las cuales pueda experimentar con su identidad. Para Esnaola (2004), esta experiencia es tanto vital, como profundamente placentera ya que posibilita a la estructura mental del sujeto, conectarse con la riqueza de su propia creación y reconocerse a sí mismo en el placer de hallar la autoría de su pensamiento.

El sujeto entonces desarrolla la capacidad de "estar a solas" con su pensamiento hallando placer en ese instante que, lejos de concebirse como un movimiento interior de aislamiento, se configura en una fuerza centrífuga proveedora de energía erotizada que le permite comunicarse con los otros desde su propia y genuina experiencia de vida (Esnaola, 2004:152-154).

\section{Aspectos sociales}

Sobre los aspectos sociales, Esnaola (2004) estudia la identidad en este contexto desde lo que denomina prácticas culturales híbridas. La autora enuncia la existencia de un "espacio transicional" que transcurre "entre" los sujetos y la cultura, cuyos cimientos aparecen en la primera infancia y en los primeros vínculos, pero que no se agotan en ella. En este interjuego entre la cultura y la vida de la persona individual emerge la subjetividad.

La subjetividad puede entonces considerarse como una producción intersubjetiva y social y por lo tanto, históricamente construida. Es un proceso dinámico de "historización permanente" vinculada con las huellas que se producen a partir del encuentro con los otros y con los significados culturales (Esnaola, 2004:19).

Esnaola (2004) define la identidad como un proceso de "institucionalización de la subjetividad" que se va construyendo a lo largo de la historia de los propios sujetos en sus múltiples encuentros con entes y figuras institucionales.

Desde esta mirada, la experiencia sociocultural en la cual se inscribe el sujeto, puede desplegar o inhibir diversos aspectos de la subjetividad y también formar nuevas huellas. Señalamos entonces que los procesos intersubjetivos y la experiencia social le imponen al psiquismo una demanda que permanece a lo largo de la vida, en un interjuego de permanencia y cambio continuo (Esnaola, 2004:20).

Esnaola (2004) afirma entonces, que desde esta concepción teórica, la identidad debe entenderse como "producto intersubjetivo y cultural". El Yo, construido a partir de identificaciones primarias, es un entramado complejo, una urdimbre relacional y social. 
Entonces, la certeza de una identificación única ya no puede sostenerse dado que esta posibilidad del sujeto de flexibilizar el proceso identificatorio multiplica ese espejo primitivo en una necesaria red de múltiples espejos familiares, grupales y sociales, entre los cuales los medios de comunicación y la digitalización de los mensajes - en el contexto de la cultura actual- también se sitúan como un "otro" de creciente fortaleza. (Esnaola, 2004:21).

Estos otros Yo, que hacen parte del entramado denominado identidad, se construyen a la par con esos relatos productores delYo de los que hablaba Bruner (2003). Turkle (1997) entiende los ambientes de los videojuegos como una forma de presencia distribuida y de sustitución de la propia realidad a través de sus representaciones. Esnaola (2004) propone pensar las representaciones en estos entornos virtuales como traducciones del imaginario colectivo. Hasta el mismo marketing y la publicidad a través del consumo mediático hacen parte de estas fuerzas modeladoras aportando imágenes, modelos situacionales y hasta modificaciones idiomáticas que se transforman en lo que Esnaola (2004) denomina "marcas socioculturales".

Estas se sitúan fuertemente también en las prácticas cotidianas: usos lingüísticos, costumbres y rituales religiosos que son portadores de ese imaginario colectivo, poblado de símbolos, que sólo a través de un explícito proceso de análisis podrá constituirse en objeto de indagación desentrañando sus significaciones. Pero hasta que este proceso llegue a darse - si es que media una intervención al respecto- permanecerá integrado al mundo de lo cotidiano, de las prácticas normalizadas por el uso masivo (Esnaola, 2004:22).

Estas prácticas normalizadas, las marcas culturales, el espacio transicional que posibilita lo simbólico y la solidaridad en el discurso, permite la cohesión de los contenidos culturales y las identidades personales. Citando a Esnaola:

Podríamos entonces referirnos a una continuidad con los contenidos sociales que se vertebra en la identidad pero que, sin embargo, no impide las identidades plurales que van construyendo los sujetos en su atravesamiento por las múltiples huellas que se producen en el encuentro con los otros (Esnaola, 2004: 22).

De esta manera, puede converger la multiplicidad del Yo en una cierta coherencia. Bruner (2003) afirma -y con esto concuerda Esnaola (2006) y Sibila (2008) - que la anomalía de la creación del Yo se presenta tanto a nivel exterior como interior: 
$\mathrm{Su}$ lado interior, como gustamos decir con mentalidad cartesiana, lo constituyen la memoria, los sentimientos, las ideas, las creencias, la subjetividad. Parte de su interioridad casi seguro innata y originalmente específica de nuestra especie: como nuestro sentido de continuidad en el tiempo y el espacio, el sentimiento de nosotros mismos al adoptar una postura, y así sucesivamente. Pero gran parte de la creación del Yo se basa también en fuentes externas: sobre la aparente estima de los demás y las innumerables expectativas que derivamos muy pronto, inclusive inconscientemente, a partir de la cultura en que estamos inmersos (Bruner, 2003:94).

En esta dirección y para concluir, según Esnaola (2006) es indispensable asumir lo que hay de reproducción y creación cultural, de continuidad y ruptura, en la génesis de estas identidades.

En cada institución la urdimbre social teje sujetos y vínculos. Estos sujetos, en la construcción de su identidad despliegan ese tejido, ese texto en permanente tensión entre lo instituido y lo instituyente, entre la permanencia conservadora y el cambio creativo. Afirmamos entonces que existe un continuo movimiento que se despliega en el dinámico proceso de construcción de la identidad (Esnaola, 2006:19).

\section{Aspectos individuales del sujeto: Relación sujeto-avatar}

Como cuarta y última dimensión del objeto de estudio, es necesario pensar los aspectos individuales del sujeto que permiten cerrar el círculo. El jugador es el protagonista de la historia y se transforma con los procesos que experimenta al jugar. Ahora se trata de entender cómo funcionan tales procesos en el entorno virtual y por qué mantienen sus propiedades a pesar de tratarse de que los mundos virtuales parecen un medio tan extraño.

Para Turkle (1997) en el uso diario que los seres humanos le vienen dando al computador, la ventana se ha convertido en una metáfora poderosa para pensar en el Yo como un sistema múltiple y distribuido. Básicamente el uso cotidiano de las ventanas de la interfaz gráfica de los computadores ha posibilitado ver al Yo existiendo en muchos mundos e interpretando muchos papeles, en una especie de paralelismo, donde la vida real se termina transformando en una ventana más (Turkle, 1997:20).

La multiplicidad en el sujeto que se vislumbra en la vida off line y se manifiesta en la multiplicación de roles sociales, también se advierte y se traslada a las interacciones en el mundo virtual. El Yo sigue siendo múltiple y fluido en el mundo virtual, solo que ahora media la interacción con una máquina. En estos entornos se exploran variaciones y referentes sexuales mediante la manipulación de significantes sin mayores restricciones, y se acentúa lo que en la vida posmoderna ya era claro: la constante experimentación del Yo. 
Esta modificación continua del sentido en todo tipo de procesos sociales es considerada por Turkle (1997) una "realización del pensamiento social", una manifestación del pensamiento posmoderno caracterizado por la simulación, y por derivar de la cultura moderna del cálculo y la computación. La computadora se transforma en soporte de la relación del sujeto con el mundo virtual, en su viaje a través de la representación visual, lejos del dominio de los mecanismos internos (Turkle, 1997).

Algunos usuarios consideran el computador como una proyección de ellos mismos. Este es un ejemplo de la forma en que las personas interiorizan las relaciones con los objetos para poder expresar o representar el sentido de dichas relaciones. Aquí, según Turkle (1997), el personaje digital aparece como objeto representativo de lo posmoderno, tanto en lo que tiene de apropiación computacional, como de simulación.

El sujeto como personaje y el cuerpo como receptáculo del Yo se han puesto en duda modificando las experiencias corporales comunes, cotidianas y heredadas por otras más recurrentes a nivel virtual. A diferencia de las antiguas concepciones del cuerpo, ancladas a un lugar y particulares según las culturas y su adscripción al tiempo específico, hoy parece posible hablar de cuerpos virtuales, más generales y ubicuos.

Este mismo fenómeno es estudiado porValdés (2000) en Arte, cuerpo, identidad en el contexto urbano, en que plantea que se está viviendo una desarticulación y una 'desubstanciación' progresiva del cuerpo en la época contemporánea. Valdés señala que la culminación de esta 'desubstanciación' llega con la cibercultura que lleva al desvanecimiento de la identidad corporal en el ciberespacio. Este proceso se puede ver como una afirmación, en algunos sectores, de la obsolescencia del cuerpo en este tiempo y la necesidad de sustituirlo por elementos tecnológicos más sofisticados. ¿Pero es el cuerpo y su imagen separable y abstraíble de la complejidad humana, como para retirarlo fácilmente de una comprensión de conjunto?

Para responder a esta pregunta, primero habría que analizar la imagen corporal y su construcción. Para Paul Schilder (1989) la construcción de la imagen corporal surge como parte de la dualidad sensación-acción: la imagen corporal no es otra cosa que un cuadro mental, al mismo tiempo que una percepción. Schilder (1989) pensaba que la imagen corporal se extendía más allá de los límites del cuerpo, agregando objetos o expandiéndose hacia el espacio. Un cuerpo es siempre un cuerpo de la personalidad, y toda personalidad tiene emociones, sentimientos, tendencias, motivos y pensamientos (Schilder, 1989).

Para Schilder (1989) la imagen corporal no es el resultado de asimilar la imagen de los cuerpos de los demás ni del proceso de identificación con las imágenes corporales de otros, aunque implique la incorporación de parte de las imágenes de otras personas o el enriquecimiento de la visión propia del cuerpo (Schilder, 1989:203). La imagen corporal parte del cúmulo de experiencias sensitivas del sujeto y experiencias de acción tanto físicas como psicológicas. Y es así como el sujeto a partir de imágenes puede representarse a sí mismo, todo gracias a que existen unas características de identidad asociadas a todo los procesos de construcción mental y una imagen consistente de sí mismo, mediante el reconocimiento consciente del cuerpo. Sería una imagen tanto del cuerpo como de la mente, construida en base a contenidos y referentes culturales y a unos procesos mentales afines a todos los seres humanos, que, como lo plantea Turkle (1997), pueden llegar a proveer una concepción cyborg del cuerpo. 
Las imágenes de las máquinas se han acercado siempre a las imágenes de las personas, como imágenes en las que podríamos leer nuestras emociones a través de escáneres cerebrales, modificar nuestras mentes a través de la reprogramación y atribuir elementos significativos de la personalidad a nuestro código genético (Turkle, 1997:225).

¿Qué es lo que pasa con estas imágenes?, y ¿cómo podemos hablar entonces de imágenes mentales y llegar al avatar como imagen representacional de un sujeto? Respondiendo a estas preguntas Belting (2009) propone que la función de la imagen es simbolizar la experiencia del mundo y representar el mundo. Para él estas imágenes pueden ser imágenes interiores (propias del cuerpo) y exteriores (necesitan de un cuerpo técnico de la imagen para ser vistas).

Aunque las imágenes internas no siempre son de naturaleza individual, cuando son de origen colectivo se interiorizan tanto que se las llega a considerar como imágenes propias. Si recordamos a Esnaola (2004), estas imágenes hacen parte de esa discursividad que está alineada socialmente. Es así como pasan a transformarse en imágenes colectivas, lo que significa que no sólo se percibe el mundo como individuos, si no que se hace también de manera colectiva, lo que supedita la percepción a una forma determinada por la época y la cultura. Citando a Belting:

La producción de imágenes es ella misma un acto simbólico, y por ello exige de nosotros una manera de percepción igualmente simbólica que se distingue notablemente de la percepción cotidiana de nuestras imágenes naturales. Las imágenes que fundamentan significados, que como artefactos ocupan su lugar en cada espacio social, llegan al mundo como imágenes mediales, el medio portador les proporciona una superficie con una significado y una forma de percepción actuales (Belting, 2009:25).

Para entender mejor esta naturaleza simbólica y cómo se ata a lo material, es importante pensar el concepto de medio trabajado por Belting (2009) a través de Marshall McLuhan, quien consideró los medios, ante todo, como una extensión de nuestros propios órganos corporales. McLuhan (1964 y 1997) entendió a los medios como prótesis del cuerpo en la medida que mejoran nuestra aprehensión del tiempo y del espacio, muy diferente al modo como han sido entendidos en la historia del arte que ha asumido a los medios como géneros y materiales a través de los cuales los artistas se expresan. En oposición a esta concepción, Belting los entendió como medios portadores o medios anfitriones que requieren de las imágenes para hacerse visibles, es decir, son medios de la imagen (Belting, 2000:35). 
En lo que se refiere a las imágenes, se mantiene todavía una argumentación similar a la que se desarrolló para el lenguaje. Las imágenes interiores y exteriores caen indistintamente en el concepto de imagen. Es evidente, sin embargo, que en el caso de las imágenes los medios son un equivalente de lo que la escritura es en el caso del lenguaje (Belting, 2009:36).

Es así como por convención se ha llegado a entender que la imagen tiene siempre una cualidad mental y el medio siempre una cualidad material, aún si en la experiencia del sujeto se sitúa como una sola. Turkle (1987) sugiere, en el caso de la pantalla -considerada actualmente el medio dominante, lugar privilegiado de disposición de imágenes para su manifestación- que contribuye a una nueva forma de percepción para el ser humano al anular el vínculo físico entre imagen y medio, sin limitarla, y por el contrario, expandirla en el tiempo y el espacio, lo que lleva a Belting a pensar que:

El mundo virtual, que es el tema aquí, niega la analogía con el mundo empírico, y ofrece impresiones trans-corporales a la imaginación, aunque estas impresiones continúan en sí mismas ligadas de un modo contradictorio a nuestras formas endógenas de precepción.

A pesar de esa disparidad y los argumentos en contra de una continuidad en la relación con la imagen, se mantiene su propiedad de cambiar de acuerdo al momento histórico, solo que en base a una nueva relación, en la que el soporte tradicional de la imagen se concibe hoy como una ventana (Belting, 2009:50).

Lo anterior permite entender que se sigue hablando de imágenes, aunque varíe la naturaleza y tipo de soporte en que se manifiestan, incluyendo algunos que son poco convencionales. De hecho cuando se habla de realidad virtual, esas imágenes erróneamente llamadas "imágenes virtuales" cuando constituyen, más bien, imágenes de mundos virtuales- son, en palabras de Belting (2009), "imágenes de un mundo que existe únicamente en imágenes" (101).

Las imágenes como expresión de la experiencia del cuerpo permite -como en el caso del avatar- trasladar la visibilidad de los cuerpos a la visibilidad que poseen las imágenes a través de sus medios, mediante los espacios simbólicos con los que el ser humano construye el sentido de las cosas y de sí mismo.

Es aquí donde el avatar aparece como mediador entre el sujeto y los mundos virtuales, como soporte de la imagen mental que denominamos imagen corporal, con todos sus contenidos y sus particularidades, representando visualmente -tanto como la interface gráfica lo permita- las distintas facetas de la identidad de un sujeto, dependiendo del mundo virtual creado por los diseñadores de videojuegos.

Los avatares no solo permiten representar las expresiones de identidad en el espacio digital. Para Hamilton (2009) ellos también realizan un complejo rango de funciones 
interrelacionadas, como facilitar la expresión de motilidad física, a través de la expresión no verbal, o ayudar a mediar la interacción en ambientes conectados a una red. Cuando son bien diseñados, pueden contribuir al sentido de "presencia" (sensación de estar ahí) y al sentido de "co-presencia” (sensación de estar ahí con otros en un espacio digital (Hamilton, 2009:2). De forma afín a Hamilton, Kromand (2007) define el avatar como "el protagonista del juego y funciona como mediador entre la ficción y el jugador" (1), cuya individualidad y presencia en el espacio físico son propiedades determinantes del avatar.

En un nivel básico, Hamilton (2009) dice que un avatar describe la manifestación de sí mismo en el mundopantalla, y Kromand (2007) lo ve como una unidad de juego que está bajo el control del jugador. Estas dos ideas nos pueden llevar al entender las manifestaciones del Yo y el control como la intención manifiesta del sujeto. Volviendo a la idea de mundo-pantalla, para Hamilton (2009), un avatar provee la expresión de identidad. En el espacio de la red, este proporciona un medio de comunicación no verbal, que moldea la forma en la que nos presentamos a otros y como ellos responden a nosotros. El avatar también cumple una función locativa en la interface y, por extensión, facilita la expresión de nuestra motilidad a través del espacio de la pantalla (Hamilton, 2009:2).

El nivel de inmersión y pertenencia que se puede llegar a presentar a nivel del personaje, puede resultar tan profundo que, no solamente el sujeto jugador dirija al avatar a través de su movimiento, sino que también se encuentre involuntariamente esquivando y zigzagueando los obstáculos que se encuentren en el desarrollo del juego. Este proceso de relación espacial sujeto-avatar es denominado por Hamilton (2009) como proceso de interacción incorporada. De la misma forma para Kromand (2007), las señales de identificación que da el sujeto se pueden ver como identificación central, cuando el jugador ve a través del avatar y hay una conexión causal entre las acciones del jugador y los eventos del juego, o también como identificación acentral en el que el jugador ve-emocionalmente- el avatar como una tercera persona (Kromand, 2007:2).

Por otro lado, el sujeto jugador a nivel de la construcción de sentido, aborda los elementos gráficos disponibles (los presentes en la interface gráfica del MMORPG) desde una dimensión semiótica (proceso de semiósis) y estética. Desde su subjetividad, el videojugador le da sentido a las imágenes prediseñadas del juego que funcionan como significantes, portadores de unos significados personales y otros culturales. Para Mandoki (2006), la subjetividad es la condición de posibilidad de la identidad (sin sujeto no hay sustrato para la identidad), como la individualidad lo es de la subjetividad (sin vida no hay sujeto).

La subjetividad brota de la individualidad en el mero acto de hacer, que se objetiva en identidades. Las condiciones colectivas de la identidad son las matrices o instituciones que establecen las reglas de su estructuración y manifestación. Pero la función de la subjetividad no se limita a ser sustrato de la identidad sino que es el punto de integración de realidades internas y externas, privadas y públicas, personales y sociales, y sobre todo, presentes, pasadas y futuras permitiéndonos reconocernos como uno y el mismo a lo largo del tiempo y a través de distintos espacios sociales o matrices. La subjetividad es al mismo tiempo co-subjetividad entre varios sujetos e inter-identidad en el sujeto. La inestabilidad resultante de la multiplicidad de identidades en distintos contextos es controlada y equilibrada por la subjetividad (Mandoki, 2007:77). 
La inestabilidad resultante de la multiplicidad de identidades en distintos contextos es controlada y equilibrada por la subjetividad, y es mediante el proceso de subjetivación que el sujeto interioriza el mundo que lo rodea. Así, después de interiorizadas las imágenes a través de la subjetivación, el sentido de estas imágenes es valorado estéticamente en el proceso de subjetivación y finalmente plasmado mediante la elección de los elementos gráficos, a través del proceso de objetivación, es decir, el proceso que usa para exteriorizar el sujeto, en este caso mediante una representación que lo identifica (avatar).

Este componente estético del proceso, desde la prosaica o valoración, responde a la dicotomía objetivismo-subjetivismo que plantea Mandoki (2006): mediante un proceso dinámico de subjetivación/objetivación, el sujeto constituido desde la objetividad de lo social, valora el objeto que solo existe en tanto que es subjetivado por él. La percepción de este objeto por el sujeto no afecta al objeto en sí, pero sí al sujeto y a su percepción del objeto. El sujeto no alucina las características de los objetos, solo comparte códigos y sentidos alrededor de estos y los confronta en su relación con ellos.

La producción de la identidad es no solo una actividad semiótica para significar y simbolizar quienes somos, sino propiamente estética al implicar un quehacer y una intencionalidad apuntados hacia su valoración y apreciación por los otros (Mandoki, 2006:76).

Entonces, cuando el sujeto jugador se enfrenta a la interface de creación de personajes, se apropia de los contenidos ofrecidos por el diseñador del MMORPG -tanto personales como culturales-, interiorizando las imágenes prediseñadas, dándoles sentido, valorándolas (no necesariamente en ese orden, ya que este proceso se da en ambos sentidos) y posteriormente eligiendo los elementos que de acuerdo a la ocasión, las necesidades y los otros elementos motores de la representación, dan forma a su avatar.

El avatar posee cuatro indicadores de la dimensión de aspectos individuales del sujeto: raza y sexo como expresión de la identidad, es decir, referentes acerca de qué se quiere ser; la apariencia como expresión de la autoimagen, esto es referente acerca de cómo se quiere ver, y por último una clase o profesión, como expresión del rol, referentes acerca de qué se quiere hacer.

Estos tres elementos, identidad, auto imagen y rol, se pueden entender como los tres componentes de la co-subjetivación de la que habla Mandoki (2006), como proceso de subjetivación (interiorización de los aspectos de la realidad externa) y objetivación (exteriorización de la propia subjetiva). Esta co-subjetivación supone que el sujeto subjetiva los contenidos disponibles en la interfaz del sujeto y los exterioriza objetivándolos como representación de su identidad. 
Para finalizar, se presenta un esquema general de lo que se plantea como hipótesis de los mecanismos de representación de la identidad, en la construcción de avatares (ver Figura 3).

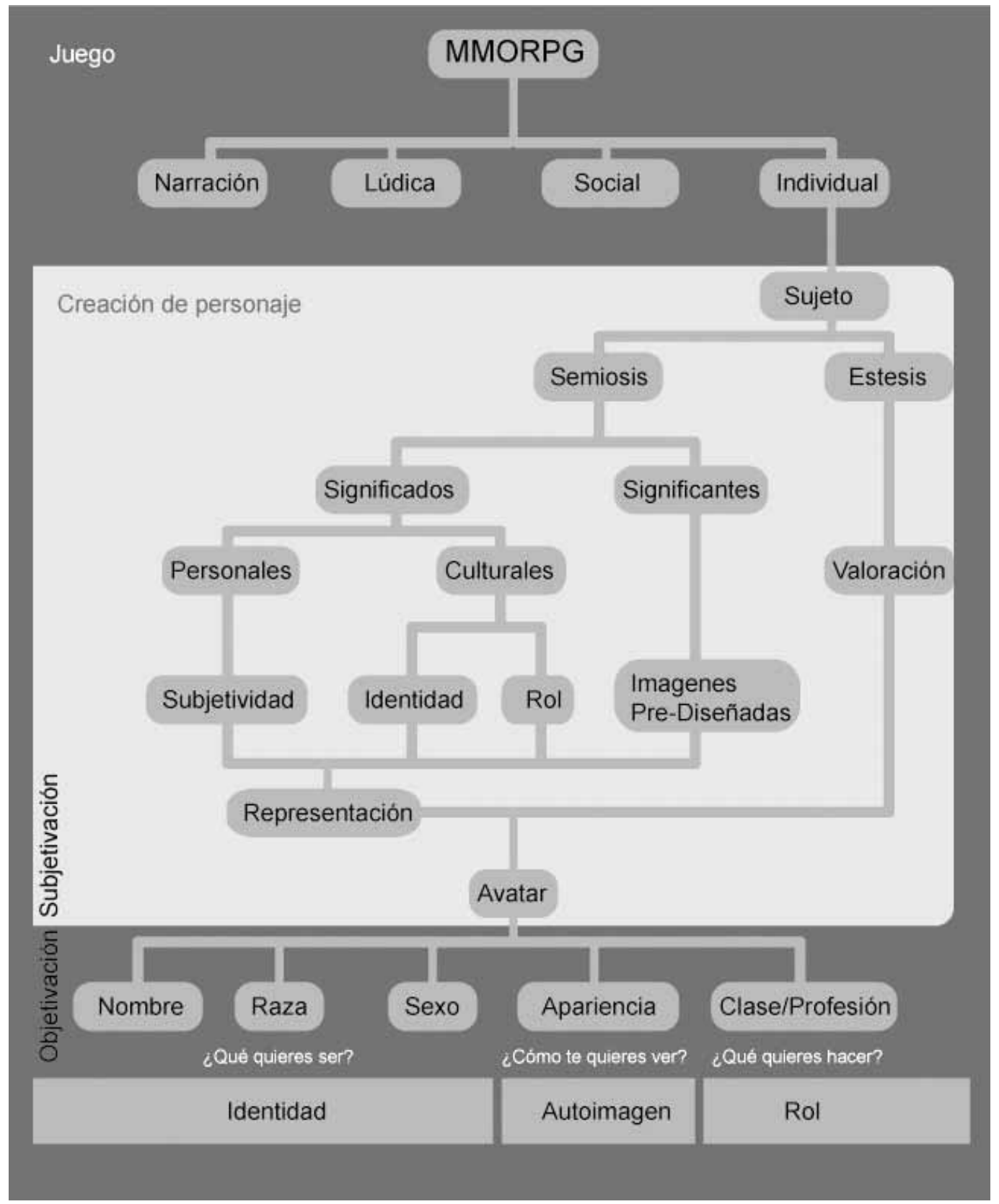

Figura 3. Esquema hipotético de la estructura de construcción del avatar. 


\section{Proyección del objeto de estudio, desde el concepto personalidad}

Una vez creado el avatar, ¿cómo se puede saber qué elementos de la identidad han sido filtrados por la subjetivación y representados en el avatar? Pues así como el agua deja sus marcas cuando pasa por un lugar, todo el proceso anteriormente mencionado no desaparece simplemente en la inmensidad del pensamiento del sujeto, sino que se mantiene, hace parte de él y de procesos posteriores. Turkle (1997) hace referencia a esto retomando las palabras de Lacan: "las complejas cadenas de asociaciones que constituyen el significado para cada individuo no conducen a un punto final o a un yo esencial", lo que le permite ver, "al ego como ilusión, el yo como un reino de discurso más que como una estructura permanente de la mente” (227).

En esta dirección, la psicología en sus esfuerzos por encontrar métodos confiables para analizar la personalidad del ser humano, ha desarrollado un amplio corpus teórico. Algunas vetas de estudio psicológico encuentran que en el dibujo las personas muestran aspectos importantes de la personalidad. El trabajo de Karen Machover (1974) sostiene que:

La personalidad no se desarrolla en el vacío, sino a través de los movimientos, sentimientos y pensamientos de un cuerpo específico. Los métodos proyectivos para explorar las motivaciones han puesto repetidamente al descubierto determinantes profundas y quizá inconscientes de la expresión de individualidad, las cuales no podían manifestarse en la comunicación directa. Sin riesgo alguno se puede dar por sentado que toda actividad creadora lleva el sello específico de los conflictos y necesidades que ejercen presión sobre el individuo que crea (Machover, 1974:4).

Para Machover (1974) "la experiencia basta y concentrada en dibujos de la figura humana indica una conexión íntima entre la figura dibujada y la personalidad del individuo que hace el dibujo" (4). Cuando el sujeto intenta resolver el problema de construir su avatar, se ve obligado a crearlo a partir de los elementos disponibles en la interface de creación, en un orden que tiene sentido de acuerdo a sus contenidos mentales, de igual forma que aquel que dibuja materializa una idea a partir del lenguaje de la forma que ha desarrollado, lo que tiene mucho sentido visto desde Moles (1991), para el cual, la valoración moderna de la imagen como medio de representación está basada en la centralidad del sujeto como sustrato de determinación de la significación y como referente de realización y extensión de sus fines (Moles, 1991:28).

De esta manera se puede entender que este mismo sujeto al escoger una serie de elementos gráficos prediseñados, apela a esta misma conexión partiendo de la propia subjetividad, en un acto igualmente creador. El proceso no es materialmente el mismo pero su sentido es análogo, ya que en algún momento entra en un proceso de selección que implica identificación a través de la proyección ${ }^{3}$ y la introyección ${ }^{4}$. 
Según Machover (1974) en estos procesos "el individuo debe dibujar conscientemente, y sin duda inconscientemente, sobre su sistema total de valores psíquicos. El cuerpo, o el Yo, es el punto de partida de referencia más familiar en cualquier actividad”. Esta asociación a la imagen corporal y a la idea del Yo, permite entender la idea de avatar como medio de interacción entre sujeto y el MMORPG, como parte del simulacro al cual se accede en el momento de decidir jugar. Asociaciones a través de la imagen, que según Moles (1991), permiten reforzar los mecanismos de transmisión de esquemas formales con un profundo sentido de identidad, los cuales serán usados para representar a esta.

De forma semejante, Vega (1995) estudiando a Cassirer, entiende la representación del sentido como una puesta en materia que debe tener un 'cuerpo sensible' concreto:

La imagen como representación material permite que el sentido perdure y se estabilice, pueda transmitirse y comunicarse. El sujeto conforma el sentido colectivo solo gracias a la mediación de la materialidad de la imagen por lo que éste pasa a ser 'rasgo objetivo', determinación de lo exterior, atributo de las cosas. Este es el proceso mismo de ‘construcción’ del sentido y de su objetivación. (21).

Esto permite entender cómo la imagen y su sentido evoluciona hacia una cierta significación pura, a partir de tres estadios:

- Signo: representa contenido de sentido de la cosa, presentándola directamente, imitándola, reproduciéndola.

- Analogía: representa materialmente de forma indirecta. Relaciones formales entre el sentido dado a la cosa y la imagen material.

- Símbolo: Contiene una significación puramente subjetiva 'cerrada sobre sí misma y organizada según reglas rigurosas'.

Esta evolución del sentido en la imagen, permite relacionar lo representado con los sentidos asociados, de forma que el avatar como representación de una identidad, es a la vez portador de estos sentidos. Paralelo a esto, para Machover (1974) "el dibujo de una persona, al implicar una proyección de la imagen del cuerpo, proporciona un vehículo natural para la expresión de las necesidades y los conflictos de nuestro propio cuerpo". Lo que lleva a pensar sobre los significados asociados a las partes del cuerpo humano, como parte de la imagen corporal. Para Machover (1974): 
El problema de cómo ciertos órganos llegan a adquirir significados evidentes de suerte que estos puedan comunicarse al dibujo de la figura humana es un rompecabezas. Basta decir, que desde el punto de vista empírico, que tales comunicaciones gráficas ocurren independientes de la edad, la destreza o la cultura. Una fuente que debe tenerse en cuenta es el significado social común que tienden a adquirir los atributos físicos en el desarrollo de la expresión y los intercambios sociales. Así ciertos tipos corporales tienden a asociarse con atributos psíquicos específicos. Convencionalmente se considera el tipo asténico ${ }^{5}$ como idealista, físicamente débil y refinado, en tanto que el pícnico ${ }^{6}$ se asocia con lo terrenal y los impulsos gregarios (Machover, 1974:7).

El análisis del problema anterior le ha permitido entender a los psicólogos la naturaleza de estas formas de representación. Para Machover (1974) el "hecho de que no podamos evadir los límites somáticos de nuestros deseos, conflictos, compensaciones y actitudes sociales tiene apoyo considerable en el fenómeno de la auto-proyección de la individualidad mediante el dibujo de la figura humana”. Un ejemplo que Machover plantea es que algunos órganos presentan tal vulnerabilidad e importancia, que se transforman en punto crucial de la vida emocional y la adaptación del (8).

Esta profunda relación de la imagen corporal con el estado de la mente humana, permite concebir los valores simbólicos que se proyectan en los dibujos, como fuente de datos psíquicos. Citando a Machover (1974):

Las interpretaciones de los valores del símbolo concuerdan con los significados psicoanalíticos y folklóricos comunes.

Su significación para la personalidad radica en el hecho de que están involucrados procesos de selección extraídos del infinito depósito de experiencias y conjunto de imágenes potencialmente disponibles, en combinación con una organización dinámica de movimiento y representación mental de lo percibido (Machover, 1974:9).

En el caso de la creación de avatares en los MMORPGs, estos mismos procesos de selección y organización pueden llevarse con distintos niveles de conciencia respondiendo principalmente a necesidades de representación o exploración de la identidad. Machover (1974) sostiene que:

La mayor parte de los dibujos contienen elementos de auto-evaluación tanto en las formas de proyección directa y compensada como en las fases consientes e inconscientes de auto-revelación ${ }^{7}$.

La comprobación de los aspectos inconscientes a menudo puede obtenerse del estudio de la historia clínica del sujeto, del patrón de personalidad reflejado en otros test y, frecuentemente, de las propias asociaciones que de sus dibujos da el sujeto (Machover, 1974:9). 
Finalmente, es importante entender que las pruebas desarrolladas alrededor del trabajo de Machover (1974), no están diseñadas para ser aplicadas de forma directa al avatar, pero aportan elementos de análisis y herramientas que posibilitan generar un modelo metodológico para comprobar sus planteamientos e hipótesis, ya que aunque "de ningún modo puede suponerse que cuando un individuo se pone a hacer un dibujo queda inmediatamente atrapado por todos los aspectos conscientes de su cuerpo" (Machover, 1974:10), si se pueden rastrear los procesos que lo llevaron a construir el avatar.

En el caso del análisis de la figura humana, se puede encontrar este tipo de rastros en los ejemplos que ofrece Machover (1974):

Por ejemplo, un sujeto impresionable, pequeño y desnutrido se siente impulsado a dibujar un ego-modelo poderoso, de hombros formidables. Del mismo modo, un sujeto obsesivo-compulsivo que manifiesta deseos conscientes de que ojalá pudiera ignorar el control de su cerebro y regirse por los impulsos brutales de su cuerpo y la fuerza muscular de sus brazos, ciertamente dibuja un cuerpo viril, con unos brazos largos como de mono y una cabeza diminuta que precariamente se balancea sobre el cuerpo (Machover, 1974:10).

Finalmente, los avatares son imágenes altamente icónicas y sus referentes en el mundo real posibilitan la identificación del jugador con el objeto simbólico que lo representa en el mundo virtual. Los avatares en su construcción poseen un sentido figurativo que anima una voluntad de decir, explicar o dar sentido mediante la expresión, lo que Moles (1991) denomina discurso icónico, uno que se desarrolla en las profundas relaciones entre la imagen y lo que representa. En este caso lo que el sujeto jugador quiere representar a través de su avatar, se logra mediante la configuración de imágenes prediseñadas, como elemento significantes en una representación visual consistente de la imagen corporal del jugador o de la concepción ideal de sí mismo.

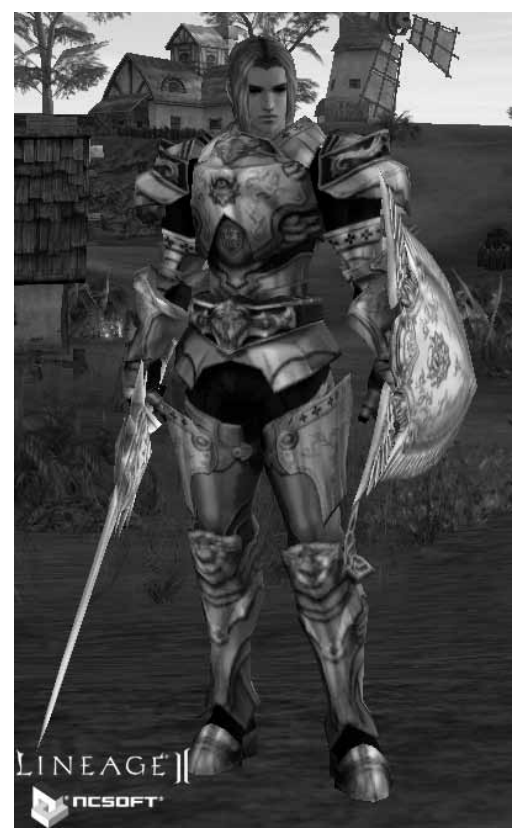




\section{Notas}

${ }^{1}$ World of Warcraft: es un videojuego de rol multijugador masivo en línea (MMORPGS) que fue de sarrollado por Blizzard Entertainment. Es el cuarto juego establecido en el universo fantástico de Warcraft.

${ }^{2}$ La ontología es el estudio de los conceptos a priori que residen en el entendimiento y tienen su uso en la experiencia, llevando la noción hacia un sentido más inmanente.

${ }^{3}$ La proyección es un mecanismo de defensa que opera en situaciones de conflicto emocional o amenaza de origen interno o externo, atribuyendo a otras personas u objetos los sentimientos, impulsos o pensamientos propios que resultan inaceptables para el sujeto. Se «proyectan» los sentimientos, pensamientos o deseos que no terminan de aceptarse como propios porque generan angustia o ansiedad, dirigiéndolos hacia algo o alguien y atribuyéndolos totalmente a este objeto externo. Por esta vía, la defensa psíquica logra poner estos contenidos amenazantes afuera. (Roudinesco, Elisabeth; Plon, Michel (2008) [Primera publicación (Dictionnaire de la Psychanalyse), 1997]. «Artículo: Proyección». Diccionario de Psicoanálisis. Traducción: Jorge Piatigorsky y Gabriela Villalba. Buenos Aires: Paidós.)

La introyección es un proceso psicológico por el que se hacen propios rasgos, conductas u otros fragmentos del mundo que nos rodea, especialmente de la personalidad de otros sujetos. La identificación, incorporación e internalización son términos relacionados. La introyección es también el nombre de un mecanismo de defensa en el que las amenazas externas se internalizan, pudiendo neutralizarlas o aliviarlas; de manera similar, la introyección de un objeto o sujeto amado (por ejemplo, una persona de gran importancia) reduce la ansiedad que produce el alejamiento o las tensiones que causa la ambivalencia hacia el objeto. Se considera un mecanismo de defensa inmaduro. (Roudinesco, Elisabeth; Plon, Michel (2008) [Primera publicación (Dictionnaire de la Psychanalyse), 1997]. «Artículo: Proyección». Diccionario de Psicoanálisis. Traducción: Jorge Piatigorsky y Gabriela Villalba. Buenos Aires: Paidós).

${ }^{5}$ Etimológicamente significa cierta debilidad del organismo; falta de fuerza. tronco y miembros esbeltos, delgados; hombros estrechos y caídos, musculatura débil, cráneo pequeño, manos delgadas, tórax aplanado, ángulo esterno-costal agudo, rostro alargado y estrecho. Temperamento esquizoide o esquizo-tímico: hipersensitivo, tímido, temeroso, nervioso, amante de la naturaleza y de los libros. Otros individuos de este tipo son insensibles, obtusos, dóciles. (E. KRETSCHMER, Constitución y Carácter, Barcelona 1951).

${ }^{6}$ Individuo rechoncho, de formas redondeadas, estatura mediana, cuello corto y ancho, cabeza y abdomen voluminoso, ángulo esterno-costal obtuso, tejido adiposo abundante especialmente en el vientre; miembros y hombros delgados, musculatura floja. Temperamento cicloide o ciclotímico: individuo sociable, amable, de buen genio, pero cambiante, explosivo; de fuerte sentido de la realidad concreta.(E. Kretschmer, Constitución y Carácter, Barcelona 1951).

${ }^{7}$ Se puede definir como el proceso voluntario de revelar a otros, información sobre uno mismo. (Social penetration: The development of interpersonal relationships. Altman, Irwin; Taylor, Dalmas A.Oxford, England: Holt, Rinehart \& Winston. (1973).

VIII 212 pp.)

\section{Referencias}

Bates, M. (2009). Persistent Rhetoric for Persistent Worlds: The Mutability of the Self in Massively Multiplayer Online Role-Playing Games. Quarterly Review of Film andVideo, 26, 102-117.

Barthes, R. (2009). Lo obvio y lo obtuso. Barcelona. Paidós.

Belting, H. (2009). Antropología de la imagen. Buenos Aires. Kats.

Berger, P. L. \& Luckmann, T. (1988): La construcción social de la realidad. Buenos Aires, Amorrortu.

Bruner, J. (2003). La fábrica de historias. Argentina. FCE.

Esnaola, G. (2004). La construcción de la identidad social a través de los videojuegos. Valencia. Servei Publications.

Esnaola, G. (2006). Claves culturales en la construcción del conocimiento. Buenos Aires. Alfagrama. 
Hamilton, J. (2009). Identifying with an Avatar: A Multidisciplinary Perspective. Queensland University of Technology.

Hernández, D., y Hernández, M. (2009). La construcción de sociedades virtuales entre los jugadores masivos en internet.

Relaciones. Estudios de historia y sociedad, Vol. XXX. No.118. El Colegio de Michoacán, Zamora, Michoacán, pp.221-244.

Kromand, D. (2007). Avatar Categorization. University of Copenhagen.Copenhagen.

Machover, K. (1974). Proyección de la personalidad en el dibujo de la figura humana. Bogotá. Edit. Cultural.

Mandoki, K. (2006). Estética cotidiana y juegos de la cultura: Prosaica I. México. Siglo XXI.

Moles, A. (1991). La imagen: Comunicación funcional. México. Edit. Trillas.

Pérez, O. (2006). Teorías del Videojuego: Una aproximación al videojuego como objeto comunicativo. Universitat Pompeu Fabra.

Piuzzi, G. (2010). Videojuegos MMORPG, conceptos, características, problemáticas y posibilidades. Recuperado de http://www.ucm.es/BUCM/revcul/e-learning-innova/1/art305.pdf

Nadya González, N. Salazar, A. y Velásquez, A. (2008).

Estado del arte de la investigación sobre Juegos Masivos en Línea de Múltiples jugadores (jmlmj). Bogotá. Universidad Javeriana.

Salazar, J. (2005). On the Ontology of MMORPG Beings: A theoretical model for research. Sendai. Tohoku Gakuin University.

Sibila, P. (2008). La intimidad como espectáculo. Buenos Aires. Fondo de Cultura Económica.

Schilder, P. (1989). Imagen y apariencia del cuerpo humano. México. Paidos.

Tomoko, K., Toru, I., Matthias, R. y André, E. (2008). Avatar culture: cross-cultural evaluations of avatar facial expressions.

London. Springer-Verlag.

Turkle, S. (1997). La vida en pantalla. Barcelona. Paidos.

Psychological Association. (2009). Manual de estilo de publicaciones de la American Psychological Association. (6th ed.). Washington, DC. American Psychological Association.

Valdés, S. (2000). Arte, cuerpo, identidad en el contexto urbano. Buenos Aires. Instituto americano de investigaciones estéticas.

Vega, A. (1995). Entorno a la Materialidad de la imagen: representación, presentación, simulación.

Bogotá. Universidad Nacional de Colombia.

Recibido: febrero 5 / Aprobado: mayo 30 de 2013 